\title{
A RANGE OF INFORMATION TEST IN SCIENCE.
}

\section{By Eilliot R. Downing, University of Chicago.}

The time has come, it seems to me, when this Biology Section of the Central Association that is seriously concerned with the problems of education should cease to convene merely for discussion, and address itself to these problems in accordance with that scientific spirit for which, supposedly, we stand. In days not so very far distant biologists were wont to discuss such an unsettled point as to whether or no living things might arise by spontaneous generation. Pasteur settled that not by skill in debate, but by skilful and conclusive experiment. We all know how unfruitful in scientific results was that prolonged period of discussion following the publication of Darwin's Origin of Species and his Descent of Man. It was not until polemics ceased and experimental investigations began again, that our knowledge of evolutionary processes was once more increased.

I do not mean to imply that the former programs of our section have been without papers that presented scientific studies of the pedagogy of science; far from it. There have been occasionally excellent studies made whose results have first been announced here, but I do mean that this section has not yet consciously and steadfastly set itself to a scientific study of the problems of biological teaching.

Three major lines of investigation are immediately needed. 1. A careful survey of the schools in our Association to determine what are the present standards in biology instruction regarding aims attempted, principles that are stressed, materials that are used, and methods that are in vogue, to the end that we nay have definite, accepted standards of efficiency. 2. Experimentation to settle such disputed questions of methods and materials as can only be so settled. 3. Standardized tests that may be given to see if we are accomplishing what we set out to do.

I. The Surver, I conceive it would be a tremendously helpful thing to the biology teachers in our territory if this section could publish, in concise form, such information as would result from a careful survey of the facts as they exist. Suppose for instance we could say:

As the result of a survey of the schools of the Central Association it has been found:

(a) That the important things to come out of biology in- 
struction are as follows, stated in order of their importance as determined by the expressed opinion of the teachers.

(b) That the following are the concepts or principles or topics of biology that need most emphasis as determined by present practices.

(c) That the texts in botany, biology, physiology, and zoology in widest use in our territory are as follows, giving in addition to the names the percentage of schools in this territory in which each is used. Analyses of all the widely used texts would enable teachers to see at a glance their relative merits for a particular use.

(d) That the mean percentage of time spent on each of the animal or plant groups or on each of the important biological topics is as follows:

The mean percentage of time given to recitation is laboratory work _............; to field work with the compound microscope. ;etc.

This merely begins to suggest the things we want to know, to give us any adequate idea of what the present standards are in biology instruction in our territory. Some of the items are in part available now. But the articles in which this information occurs are widely scattered in point of time, and I imagine few if any of us could give a new. teacher all the information I have suggested as immensely helpful in formulating her work, or could apply it to ourselves in judging our own work.

II. Experimentation. There are many questions of methods and materials to be used that can only be settled by experiment. Take, for instance, one suggested by Mr. Slimn in his topics of discussion on his paper, "The High Schools of Tomorrow." "Would a change in method from the pure quiz recitation to that of demonstration and supervised study increase efficiency of work?" The answer is to be found by experiment, not by discussion. As well discuss the question, "Is close inbreeding detrimental to stock?" We have learned as biologists that the way to settle such a question is by trying it out repeatedly and keeping accurate record of results. Why not attack our questions in methodology of science instruction in the same scientific way? I know it will take a long time to get conclusive evidence on all the unsettled points. But we shall be making progress in the only way it can be made; when a problem is so settled scientifically, it is solved for good, and we shall not have to meet annually to thrash over the same question and go away none the wiser for our time and effort. 
III. Tests. Having set ourselves definite goals we must devise tests to see if we are achieving such, and I approach now the particular thing in which I want to report a slight contribution.

Please put an $\mathrm{E}$ beside words and phrases (on the list below) that you can explain or define; an $\mathrm{F}$ beside those you have heard or read about, the meaning of which is not clear; and an $\mathrm{N}$ beside those that are new. Explain or define the first three you mark with an E.

1. Action and reaction are equal.

2. Adaptation.

3. Alpine flora.

4. Angle of reflection.

5. Animal society.

6. Atom.

7. Avogadro's Law.

8. Battery pole.

9. Buoyancy.

10. Candle power.

11. Center of gravity.

12. Comet.

13. Commensalism.

14. Composition of forces.

15. Conduction.

16. Conservation of energy.

17. Dew point.

18. Differentiation of tissues.

19. Disease organisms.

20. Drowned valley.

21. Eclipse.

22. Egg.

23. Electrical resistance.

24. Electromagnet.

25. Enzyme.

26. Erosion.

27. Equinox.

28. Evolution.

29. Family tree.

30. Fertility of soil.

31. Fertilization of egg.

32. Food plain.

33. Fossil.

34. Gas diffusion.

35. Germ plasm.

36. Heat expansion.

37. Ionization.

38. Isomer.

39. Induced currents.

40. Inertia.

41. Inoculation.

42. Instinet.

43. Law of definite proportion.

44. Law of gravitation.

45. Law of the lever.

46. Law of the pulley.

47. Laws of fluid pressure.

48. Lines of magnetic force.

49. Mature topography.
50. Mendel's law of heredity.

51. Metabolism.

52. Metamorphic rock.

53. Migration.

54. Mimicry.

55. Molecule.

56. Momentum.

57. Moraine.

58. Mutation.

59. Natural selection.

60. Nebula.

61. Neap tide.

62. Nitrifying bacteria.

63. Noncomformity of rock strata.

64. Non-inheritance of acquired characters.

65. Normal eurve of variation.

66. Orbit of the moon.

67. Osmosis.

68. Oxidation.

69. Photosynthesis.

70. Parasitism.

71. Planetesimal hypothesis.

72. Plant or animal cell.

73. Polarized light.

74. Precession of the equinoxes.

75. Precipitate.

76. Pure line.

77. Refraction of light.

78. Regeneration of parts.

79. Relation of frequency to pitch.

80. Reversion.

81. Saturation.

82. Sedimentation.

83. Solar system.

84. Specialization of function.

85. Specific heat.

86. Spectroscopic analysis.

87. Spontaneous generation.

88. Stable equilibrium.

89. Star.

90. Sterilization.

91. Subatomie energy.

92. Surface tension.

93. Symbiosis.

94. Synthetic sugar.

95. The ice age.

96. Toxin. 
97. Tropism.

Male or female

98. Valence.

Grade

$7,8,9$ or 10

99. Variation.

100. Vertebrate type.

College year.

College graduate

$7,8,9$ or 10

$7,8,9$ or 10

There are a number of worth-while aims in science teaching-the achievement of certain skills, attitudes of mind, tastes, ideals, etc. Probably we would all agree, too, that some knowledge should be acquired, and the more this can be carried away by the pupil in the form of generalizations rather than as masses of unrelated fact, the more likely it is to function in his later life.

I have, therefore, devised a range of information test in science that deals with such general notions, and have been trying it out on pupils to see what percentage of these ideas are clear at various levels in our school system. I shall confine myself now to a preliminary report on the results with high school freshmen and college freshmen and sophomores.

To make up the list of one hundred words and phrases that suggest important generalizations that, it would seem, our science education should make meaningful, I went through a number of secondary texts in astronomy, biology, botany, general science, geography, physies, physiography, physiology, and zoology, and selected those that were stressed most frequently and thoroughly. I then submitted my tentative list to a number of high school teachers of such subjects, asking them to indicate what ones in their opinion should be stricken out as relatively unimportant, and to suggest any important ones I had omitted. I revised my. list then in accordance with the opinions of the majority. The list follows, together with instructions for making the same.

This test has now been given or is being given to seventhand eighth-grade pupils, high school freshmen, sophomores, juniors, seniors, college freshmen, and sophomores-some fifteen hundred in all. The resulting papers are being studied with a view to tabulating the results. The high schools which have submitted to these tests are two in Chicago, one in Illinois outside of Chicago, one each in Wisconsin and Michigan. College students have been tested in institutions in the same states and also in Missouri.

It is to be noted that in the directions for the test not only are pupils requested to mark with an $\mathrm{E}$ the terms they can explain or define, but they are asked to define or explain the first three so marked. This gives a check on the accuracy of the pupil's own estimate of his ability to satisfactorily explain or define 
the terms he marks with an E. These definitions have been looked over, and if unsatisfactory, the pupil evidently not understanding the terms he undertakes to define, his estimate of his ability is sealed down accordingly. If, for instance, a pupil marks twentyone terms with an $\mathrm{E}$, and one of his definitions shows he has the wrong conception entirely, seven of his E's are transferred to the F's. The estimates of high school pupils, it is found, must be thus scaled down on the average one-third. On the other hand, the college students' estimates of their own ability need practically no alteration.

There follow the data, thus revised, from the two Chicago high schools and from college freshmen and sophmores at DeKalb.

$108 \mathrm{U}$. High freshmen......Average 18 words marked E....30.4F 51.6N 112 Fenger Hgh. freshm'nAverage 21.5 words marked E. 17.1F 61.4N 141 DeKalb Col. freshm'n.Average 34.6 words marked E. 30 F $35.4 \mathrm{~N}$

83 DeKalb Col. soph's......Average 44.7 words marked E. $32.7 \mathrm{~F} 22.6 \mathrm{~N}$

From this tabulation it is evident that there is a rise in the percentage of words marked $\mathrm{E}$ by high school freshmen, college freshmen, and sophomores, that is quite consistent with the level of these three groups. If additional tests verify the results so far achieved, one might give the test to the freshmen of any high school and feel assured that if they achieve close to twenty per cent of E's they are an average lot as far as science training is concerned, but if they fall much below this grade or get much above it they are respectively an inferior or a superior group in this one particular.

The results of the test already show that there is great variation in the scientific attainments of the pupils in the freshmen group, or in other words the apperceptive mass measured in terms of scientific general concepts is a very variable quantity. Thus one U. High freshman marks fifty-nine out of the hundred terms with $\mathrm{E}$, and requires no sealing down, while several mark none E.

Per Cent of High School Freshmen. Per Cent of College Fenger H. S. Univ. H. S.

\begin{tabular}{rrr} 
& & .7 \\
1.8 & & 1.4 \\
2.7 & 3.9 & 5. \\
11.6 & 7.4 & 10. \\
16.8 & 26.9 & 20.5 \\
37.6 & 42.6 & 26.2 \\
29.5 & 18.5 & 21.9 \\
& & 12.9 \\
\hline
\end{tabular}

Who Marked. $80-89$ words $\mathrm{E}$ 70-79 words $\mathrm{EE}$ $60-69$ words $\mathrm{E}$ $50-59$ words $\mathrm{E}$ $40-48$ words $\mathrm{E}$ $30-39$ words $\mathrm{E}$ $20-29$ words $\mathrm{E}$ 10-19 words $\mathrm{E}$ 0-9 words $\mathrm{E}$

The above table shows the percentage of the high 
school freshmen in the two schools (U. High and Fenger), and the percentage of the college freshmen that have marked the stated number of words with an $\mathrm{E}$.

This discloses one of the great difficulties all science teachers have felt, but a difficulty we have never been able to express so clearly in figures; namely, that pupils in science classes are very inadequately graded as far as their scientific achievements and abilities are concerned. High school pupils are promoted or demoted on the basis of ability in English, mathematics, Latin perhaps, but scientific achievements or the lack of the same is ignored. Moreover, the administrative officer has often not recognized that there is a sequence in the science courses, but has put freshmen students into junior science, or vice versa. The results tabulated above from the range of information test will make apparent to the administrator who comprehends tests better than he does science, the unfairness of any scheme which brings together into one class such a heterogeneous assortment of abilities as is here disclosed.

But can the test be modified so as to be more easily given and scored, and still be as effective? Apparently fifty terms will give as good results as the one hundred. For if we consider the percentage of students who have marked each term, we find the following number of words have been marked $\mathrm{E}$ :

\begin{tabular}{ccc}
\multicolumn{2}{c}{$\begin{array}{c}\text { In the High School. } \\
\text { Fenger. }\end{array}$} & $\begin{array}{c}\text { In the } \\
\text { U. High. }\end{array}$ \\
$\begin{array}{ccc}\text { College. } \\
1\end{array}$ & 7 & 5 \\
7 & 4 & 7 \\
7 & 5 & 14 \\
10 & 5 & 11 \\
6 & 9 & 10 \\
6 & 14 & 17 \\
18 & 18 & 15 \\
45 & 37 & 14 \\
\hline 100 & $\underline{100}$ & 100
\end{tabular}

By $80-90$ per cent of the pupils By 70-80 per cent of the pupils By 60-70 per cent of the pupils By 50-60 per cent of the pupils By 40-50 per cent of the pupils By 30-40 per cent of the pupils By 20-30 per cent of the pupils By 10-20 per cent of the pupils By $0-10$ per cent of the pupils

The task that will be undertaken immediately is the abbreyiation of the list, provided the returns now coming continue to show what those now reported seem to indicate. I trust when the simplified list is ready I may have your cooperation in giving it wide trial. I further hope that this contribution, insignificant as it is as compared with the vast range of problems in the pedagogy of science, will stimulate the members of this section to plan a systematic attack on these problems in a real scientific way. 